\title{
Landscape in Literary Translation: A Comparative Study
}

\author{
Raja Lahiani \\ Department of Languages and Literatures \\ College of Humanities and Social Science, UAE University \\ UAE
}

\begin{abstract}
Translating concepts of setting can be challenging when their cultural, historical, and geographic contexts are remote from the translator's experience. Landscape is an essential factor that reveals a great deal of the culture of pre-Islamic Arabia, which is distant in place, historical framework, and literary tradition from its translators. This article examines the importance of a translator's awareness of the communicative function of source text references to landscape to adopt appropriate translation strategies. The article presents a case study of a verse line alongside a corpus of nineteen English and French translations. The source text, the Mu 'allaqa of Imru' alQays, names three mountains in Arabia, and space and distance are core themes in the verse line. Comparison is both synchronic and diachronic: at the same time that every translation is compared to the source text, it is also compared to other translations. Prose translations are also examined separately from verse translations, with cross-references in both directions. The translators who adopted source-text-oriented strategies missed communicative clues regarding the setting. However, those who endorsed target-text oriented strategies produced effective and adequate translation.
\end{abstract}

KeyWords: Imru' al-Qays, landscape, literary translation, Mu'allaqat, pre-Islamic poetry, poetry translation, spatial setting, storm scene, translation quality assessment

Cite as: Lahiani, R. (2020). Landscape in Literary Translation: A Comparative Study. Arab World English Journal for Translation \& Literary Studies 4 (3) 17-33.

DOI: http://dx.doi.org/10.24093/awejtls/vol4no3.2 


\section{Introduction}

Translation is a linguistic as well as a cultural exercise. Agency, textuality, and history are relevant, too, though they have been relatively marginalized in the scholarship of the field. With the lack of "a historical sense of the translated text, produced and received in a particular culture at a particular period, our understanding of the translator's agency has been impoverished" (Venuti, 2013, p. 7). Enkvist (1978) with good reason emphasizes that a sentence does not exist independently of text and context. Each sentence must mirror its environment so that the information appropriately "flows" through the text (p. 178). Similarly, within the framework of her investigation of extralinguistic factors and monolingual texts, Colina (2015) points out that texts are "embedded in situations or contexts that consist of non-linguistic elements, which determine linguistic form and are reflected in the text" (p.44). Such non-linguistic elements are also referred to as situational features (2015, p. 44). Of these elements, Colina (2015) says that the elements of text are function, audience, medium, time, place, and author's motive. All of these elements contribute to building up the text's message and meaning.

Spatial setting, or place as Colina puts it, is an essential element of any narrative, be it fictional or personal, as it informs the receiver of the work about where the action takes place. Kuntz (1993) rightly notes that "because this 'where' affects the nature of events as well as the audience's attitudes and expectations regarding the events," setting plays a central role in creating context and shaping a narrative (p. 3). Besides, the author of the present study agrees with Calfoglou's claim that setting in literature "may elicit a response that relies upon the audience's prior knowledge and perception of a place" (Kuntz, 1993, p. 3), or associations that the audience may link to a particular place. It is within this context, too, that one may evoke the case of a writer's or a particular audience's attachment to a particular landscape and thus the cognitive as well as aesthetic and emotional associations attributed to it. This "spatiotemporal dimension," as Calfoglou (2010) explains, may be "iconically reflected in the linguistic unraveling of the poem and information sequencing, seen as causally motivated by perception and experience, an instance of the 'synchrony' of language capturing the 'diachronic' element in human experience" (p. 87).

In the context of investigating local attachments and their relevance in creating imagery and reference in poetry, Stafford (2010) notes that the "landscape is marked by human history, the mindscape characterized accordingly by a place already steeped in meaning" (p. 37). It follows that direct nominal geographical references are significant in a literary text as they are "symbols of contested territory, making the mental map of home "some script indelibly written into the nervous system." (p. 36). Similarly, Dainotto defines what he terms "the literature of place" as the "allegorical branch that supplements the naturalistic description with a symbolic and moral vision" (p. 11).

The present article is concerned with the study of the translatability of the spatial setting which is reflected in pre-Islamic poetry. This poetry is rich with references to places and imagery related to the spatial setting. Part of this poetic tradition is that a poem opens with the poet's lamentation of his beloved's deserted encampments. The cultural, historical, and geographic remoteness of this setting makes the task of translating it a challenge. Undoubtedly, the pre-Islamic poems performed 
particular functions at the time of their composition, addressed a particular audience, and served their poets' personal motives. They were also produced in a remote time and a different place.

Translation is an interpretive act. A translator does not translate what a text says but rather their own reading and interpretation of what a text expresses and what its author intends to announce. As such, it is vital that a translator keeps in mind the situational features of the source text (ST), namely, its function, audience, medium, motive, time, and place. Furthermore, the text produced by the translator would possibly serve different functions in its receiving milieu, as this might be shifted from, say, contemplation to meditation or other. The target text (TT) would also address a different audience, as its receiver may not be aware of the original text receiver's environment. The TT may even be phrased in a different medium: Poetry is not always translated into verse; it is, in some cases, rendered into prose. Even when verse is used, differences in versification still exist between the classical Arabic tradition and Western traditions (Lahiani, 2008a, pp. 94-96). Just like the original author who composes a text with a motive in mind, so is a translator usually motivated by particular drives to translate a particular text. These influence the ultimate quality of their work. Likewise, ST and the TTs are produced at different times, and sometimes even in different historical contexts. The same would apply to place, as the original text may refer to locations or infer them; these may not necessarily appeal to the translation reader. Besides, they may not perceive their communicative value in the text translated. To this effect, Colina (2015) lines up with Skopos theory's recommendation to use the extra-linguistic factors associated with the TT to inform translation decisions (p. 53). Baker (2014) emphasizes that "[e]very translation operates within a specific, local environment, but it also contributes to the stock of narratives circulating within and beyond that environment" (p. 160).

Pym and Turk (2004) explain that translation between languages utilizes the same procedures as those used in intralingual and intersemiotic 'translation' (p. 275). They suggest some examples such as "to proceed from less to more developed expressions, to fill gaps in the lexical inventory or in the grammatical structure, or to deliver information that is made obligatory by the grammar of a particular language" (p. 275). As such, translatability strongly depends on the characteristics of the target language, particularly its translation culture (2004, p. 276). Likewise, Baker (2014) argues within her expansion on the translation of context in a narrative that it cannot be expected that without certain context-dependent modifications, meaning will be transferred entirely intact and assumed to function in the same manner across narratives. The present article argues that in such cases, target-text oriented translation techniques would be most suitable to achieve equivalence between ST and TT communicative strategies. These include modulation, which consists of the departure from an ST norm to a TT norm, and selective appropriation, which gives the translator the ability to take such decisions as omitting elements from the text, interpolating elements, backgrounding, and, or foregrounding.

The current article intends to demonstrate that a translation needs to accommodate textual as well as extratextual and intertextual factors. It adheres to the theory that translation is an interpretive act par excellence and to the concept that non-linguistic details contribute to revealing the message along with the words. It also claims that source-text oriented translation strategies and

Arab World English Journal for Translation \& Literary Studies 
techniques such as literal translation, calque, and borrowing result in a loss of textual meaning if adopted. House states that the concept "function' presupposes that there are elements in a text which, given appropriate tools, can reveal a function" (House, 2014, p. 249). She clarifies that in a text, pragmatic function is defined in terms of its application "in a particular context of situation" (p. 249).

This article consists of a case study of verse line 73 from the $M u$ 'allaqa $a^{\mathrm{i}}$ of Imru' al-Qays. The $M u$ 'allaqāt is a compilation of seven canonical odes that were recognized in pre-Islamic Arabia as masterpieces and hence (as it seems) hang upon the curtains of the Kaaba Temple. These poems mirror life in pre-Islamic Arabia, along with details about their respective poets' lives and meditations. The $M u$ 'allaqāt verses are historically and geographically remote from the Western translators of the corpus chosen for comparison. These poems' situational features are specific to them and their settings. This case study deals with landscape in the Mu'allaqāt. Landscape has not been extensively explored in any work up to this point, ${ }^{\text {ii }}$ but it is an important element because the way it is handled can determine the quality and readability of a translation.

The $M u$ 'allaqāt have been translated into different languages since the late eighteenth century. Translators have different motives, sources, priorities, and intellectual backgrounds. A translator's motives affect to some degree the way they handle features of a text. When it comes to culturespecific issues and details related to setting, the problematic is even more acute. Setting is a significant factor that reveals a great deal of the culture of pre-Islamic Arabia, which is remote in place, historical framework, and literary tradition from its translators. The researcher has chosen a corpus of nineteen English and French translations to study the renderings of the functional landscape of verse line 73 from the Mu 'allaqa of Imru' al-Qays. Of these, seven are in prose and the rest in verse; fourteen into English and five French. The first translation in the corpus was published in 1782, the last one in 2000. Due to such diversity in the corpus, the methodology adopted in this research work is comparative. Comparison is conducted at both the synchronic and diachronic levels; every translation is compared to the ST and then to previous translations. The prose translations are dealt with separately from and prior to the verse translations. In addition to adhering to the semantics and aesthetics of the source texts, verse translations are also expected to be produced as poetry (Underhill, 2016; Lahiani, 2008a). This reflects the importance of a translator's awareness that the landscape in the ST has a communicative value and impacts his/her interpretation of the text and, hence, the quality of the translation regardless of its being translated into prose or verse.

\section{Case Study Presentation:}

Imru' al-Qays (500-540) is a leading poet in pre-Islamic Arabia who emerged from a royal lineage. Though he led a carpe diem lifestyle, he adhered to such social values as generosity and chivalry (Stetkevych, 1993, pp. 241-242). He composed his Mu'allaqa to describe his amorous adventures, while at the same time, he adhered to the classical structural composition of the Arabic poem. The thematic structure of the classical Arabic poem runs through a ternary model: longing for a lost love (nasīb); departure, with the account of the mount - the horse or the camel (rahīl); and selfpraise (fakhr). He opens the $M u$ 'allaqa with a lament on the departure of his beloved and he recalls 
his past amorous adventures with many maids, boasts his virtues and those of his horse, and concludes with a detailed description of a violent storm witnessed from the shelter to which he has been forced to retreat because of the weather conditions. Descriptions of rain and storms are not infrequent in ancient Arabic poetry. These are conventionally referred to in literary criticism as "the storm scene" (Hussein, 2009, pp. 3-6). In his storm scene, Imru' al-Qays notes that the rain resulted in a severe flood, which caused great damage to the surrounding environment. The verse line quoted below is from the storm scene that concludes Imru' al-Qays's Mu'allaqa:

\section{'Alā Qațanin bil shaymi aymanu șawbihi wa aysaruhu 'alā l-Sitāri fa Yadhbuli}

This verse line refers to three different mountains in the Arabian desert: Qațan, Sitār, and Yadhbul. As these mountains are cited in the context of the poet's description of the density and expansion of clouds, it is crucial to know that, whereas Sitār and Yadhbul are relatively close to each other, Qațan is more distant: 522 kilometres separate Qațan from Yadhbul, while Sitār is only around 200 kilometres away from Yadhbul. The linker " $f a$ " in Arabic communicates progression. Literally, thus, Imru' al-Qays says that the right side of the cloud lies over Qatan whereas its left edge moves over Sitār and then Yadhbul. This distance functions as a means for the poet to describe the degree and extent of the storm clouds. The poet uses in the first hemistich the word "shaym," meaning looking at the clouds "from afar." "iii Al-Zawzani (2013) defines this word as meaning looking at the thunder while waiting for rain that is looking attentively. The use of the word "shaym" allowed Imru' al-Qays to connect the different parts of the landscape in front of him, hence the importance of visual perception. This also informs the reader that his perspective offered him a panoramic view of the terrestrial and celestial landscapes: as he watched from afar, he saw the remote shapes of the mountains, namely their tops. In addition, Imru' al-Qays presents this information in the declarative mode, as it was possible for him to physically see what he described. The description in this image is vivid because it is specific: it relates the poet's field of vision. This verse line is an instance of local inspiration and attachment, as it reflects the poet's attentive observation of the landscape and weather conditions around him. Artistic "sensibility" merges into a whole with its "locale or area" (Dainotto, 2000, p. 9), making it the main communicative clue. Awareness of this setting characteristic is important for the reader's understanding of the verse's message and meaning.

As the ST poet deals with a world that was recognizable to him and his audience, it would be challenging to make it recognizable to English or French translators. They would be unlikely to have an idea of what the mountains looked like, the distance between them, or whether it was possible to view of them all together. It is thus crucial that translators consult reference works, maps, or Arabic commentaries to understand what the names mentioned in the verse line refer to. With the exception of Caussin de Perceval, Johnson, Arberry and O'Grady, the translators whose work was included in the corpus mention in their translation introductions or forwards the ST commentaries that they adopted. In addition, many of them reflect awareness of earlier translations.

\section{The Translations: A Critical Analysis}

Arab World English Journal for Translation \& Literary Studies 


\section{Prose Translations}

William Jones (1746-1794) is the first translator who rendered the full text of the Mu'allaqät into English. His translation, done into prose, was first published in 1782 and it shows his awareness of the original poet's visual perception, as he used the verb "seems" in his description of the mountains: "Its right side seems to pour its rain on the hills of KATAN, and its left on the mountains of SITAAR and YADBUL" (1782, p. 13). Not only does this verb reflect the visual perception that is used by the poet, but it also helps show relativity in the image depicted, by focusing on the fact that what was translated was nothing but an account of the poet's. In addition to this verb, Jones adds some phrases to explain the proper names mentioned in the ST: "the hills of" and "the mountains of." Such additions are important in helping the TT reader through the ST setting, and ensuring the adequate reception of the imagery based on the setting. In the context of Jones's translation of this verse line, however, this becomes misleading. Jones erroneously informs the reader that Qațan is a place that has hills, and that Sitār and Yadhbul are places in which there are mountains, which does not conform to the ST meaning and hence misses its intended message.

As stated above, these mountains are mentioned in the context of describing the expansion of the clouds. Thus, it is important that the translator focuses on the long distance separating them. Studied from this perspective, Jones's translation is rather inaccurate, as it does not offer any hint about this distance. Jones, though a known traveler, rather targeted aesthetic and cultural dimensions in the $M u$ 'allaqāt. The acculturating domesticating strategy he used shows that he did not consider space references and inferences as communicative clues in the original text (Lahiani, 2008a, pp. 73-85). Al-Zawzanī's (2013) commentary on the Mu'allaqāt, used along with alTibrīzī's (1894) by Jones, makes it clear that the names refer to mountains and that distance is a key feature in this verse line.

Caussin de Perceval's (1795-1871) translation made the first step to clarify this distance and its functionality in the ST verse line: 'L'orage, autant que ma vue pouvait en juger, s'étendait à droite sur le mont Catan, à gauche sur les monts Setar et Yadhbal" (1847, p. 332) [The storm, as far as my sight could reach, expanded on the right on mount Catan, on the left on mounts Setar and Yadhbal]. By using the comparative clause "autant que ma vue pouvait en juger" [as far as my sight could reach], Caussin de Perceval maintains both the visual perception inferred in the ST and the relative nature of the information given, as it is based on visual perception. This phrase that is added by Caussin de Perceval also makes a hint to the long distance separating the mountains. The use of the word "mont" [mount] to modify the proper names is another positive aspect in this early prose translation. Throughout his translations of the Mu'allaqāt, Caussin de Perceval reflects a deep awareness of settings and their implications. Note that this translator set the exemplification of historical data as the basic motive in his work, as reflected in the title of his book: "Essai sur l'Histoire des Arabes Avant l'Islamisme" [An Essay on the History of the Arabs before Islamism].

Following the same path as his French predecessor, Raux (1856-? $)^{\mathrm{iv}}$ rendered this verse line as follows: "Ces nuages, autant que j'en pouvais juger, s'étendaient depuis le mont Katan à droite jusqu'aux monts Sitar et Yadhbal à gauche" (1907, p. 9) [These clouds, as far I could tell, expanded 
from mount Katan on the right up to mounts Sitar and Yadhbal on the left]. Getting very close to Caussin de Perceval's translation, Raux's uses the phrase "autant que j'en pouvais juger" for the same purpose as his predecessor. At the same time that it may reflect a visual experience, this phrase can also denote an intellectual one. Ambiguous as it may be, it does not convey the message intended in the ST as concretely as Caussin de Perceval's rendering. However, Raux's translation shows improvement over his predecessor's in one aspect: it reflects the distance between the mountains. This is achieved with the use of the prepositions "depuis" [from] and "jusqu' aux" [up to], which help create awareness of the distance for the reader. Raux mentions in the cover page of his book that his work is "une traduction litterale en Francais" [a literal translation into French]. As shown above, his translation is by no means literal, which justifies its efficiency.

Just like Raux, Johnson (1796-1876) intended to produce a translation that would be "as literal as possible" (1894, Preface). In his handling of this verse line, he does not add any strings to modify the names mentioned in the ST: "In looking for the rain, we guessed that the right of its downpour was over Qatan, while the left of it was upon Satār and beyond it upon Yazbul" (1894, p. 27). Being produced for "nothing [but to be "an aid to the students" (1894, Preface), it is doubtful that such a resolution not to explain the names would have helped the students understand the place references in this sentence. In a note, Johnson explains that "these places are very far apart, hence the magnitude of the storm is described" $(1894$, p. 27$)$. It is clear from these words that the proper names refer to places, and that these places are far away from each other, which is in itself positive. No hint is there, though, to specify that these places are mountains. Not only does this conceal information about the ST environment, but it also obscures the translation reader's awareness of the poet's field of vision, which stands as a communicative clue in the original verse line. Moreover, Johnson's use of the phrase "we guessed" shifts the poet's experience from the sensuous perception to an intellectual one, which breaks with the ST reference to the spacious nature of the setting.

Bateson (1939-), whose translation was published long after Johnson's adopted the same strategy as she shifted the visual perception inferred in the ST into a modernized intellectual one with "forecast": "Above Qatan, by the forecast-of-lightning, is the right of its downpour and its left is on al-Sitār and Yadhbul" (1970, p. 142). Unlike the previously dealt with prose translators, Bateson does not clarify that the distance between the mountains was rather long; nor does she make any hint to explain the referents of these names. Bateson's main interest in her work with the Mu'allaqāt is the study of the internal structures of the poems that link units together (1970, p. $14)$.

Schmidt (1939-) did not underestimate the importance of the visual perception in conveying part of the message of this verse line. His translation reads as follows: "A bien l'observer, j'imaginai que de son côté droit devaient tomber des gouttes de pluie sur le mont Qatan et que son côté gauche avait crevé au-dessus des monts Sitar et Iadhboul' (1978, p. 64) [By observing it well I imagined that by its right side droplets of rain would fall on mount Qatan, and that its left side would burst on Sitar and Yadhboul]. Schmidt opens his translation of this verse line with the expression "à bien l'observer" [by observing it well], which makes it clear that the poet was 
describing a scene that he managed to witness by himself. Schmidt adds the phrase "j'imaginai," [I imagined], but he attributes it to rain falls and not to the poet's visual perception of the mountains. Schmidt says that he adopted al-Zawzani's commentary in his translation, though he was aware of such old commentaries as al-Tibrīzì's, al-Naḥhās', and al-Anbārī's (p. 37). In his commentary, al-Zawzanī highlights the productivity of the expanding cloud, to which he relates his interpretation of the word "shaym." Thus, Schmidt's translation is accurate as it conveys the poet's field of vision and also clarifies the proper nouns. Schmidt uses the word "mont" [mount] to modify the mountain names, and he also explains in two endnotes that these are two mountains, after which he specifies their geographic locations (p. 71). It is rather disappointing that he does not indicate the great distance between these mountains.

As regards the visual perception, Ghani Tengku Jusoh (1959-) shifts it into the field of the intellect: "Over Qatan as predicted lay the right side - its left over al-Sitar and Yadhbul" (1990, p. 13). The difference between Ghani Tengku Jusoh's use of the verb "predicted" and Schmidt's use of "j'imaginai" is that the latter, as explained above, backs this verb with a clause that denotes the speaker's use of the visual perception in his experience with the setting, and he also uses it to refer to the speaker's rain forecast. As Ghani Tengku Jusoh simply uses the verb "predicted" in translating the poet's perception of the environment around him, he minimizes the reader's feeling of the visual perception and thus he directs it much more towards the intellectual one. Unlike Schmidt, too, Ghani Tengku Jusoh does not modify the proper names, and so in his translation the referents of the names Qatan, Sitar, and Yadhbul are not made clear. Much like his French predecessor, this translator does not indicate the great distance between these mountains, either. Note that like Schmidt, he relied on al-Zawzanī's commentary (1990, pp. 131-132).

Ghani Tengku Jusoh's translation is transcribed in his book A Critical Examination of Five Poems by Imriu al-Qays (1990), in parallel with the Arabic verse lines presented in Arabic script. It is clear from the title of his book that translation for him was used as a means for another end, which is the "critical examination" of the poetry of Imru' al-Qays. It is also highly likely that he relied on the edition of the Arabic verse lines to support his translated text, which was meant to be a close rewording of the ST with no aesthetic ambitions. He explains that his translation is pared "to the barest essentials" to get "the poet's concerns and themes $[\ldots]$ with succinct precision" (1990, p. 59).

Like Ghani Tengku Jusoh, A. Jones (1933-) appended the original Arabic text to his book (1996). Contrary to the former, however, for Jones translation is one of the three primary aims of his book entitled "Early Arabic Poetry: Select Odes. Edition, Translation and Commentary" (1996). His edition is not, thus, appended to support his translation. Alan Jones wanted his work to be didactic, and thus, he recommended that the translation should be read with the Arabic text and the commentaries, as well (1996, p. vii). Despite the difference in objectives between Jones and Ghani Tengku Jusoh, there is a close resemblance to the work of Ghani Tengku Jusoh in Jones' translation: "As far as we could tell the right hand of its downpour rose over Qatan and its left over al-Sitār and Yadhbul" (1996, p. 83). Not only are the proper names left non-modified here, but also the distance between the mountains is not clarified. Moreover, Alan Jones commits a

Arab World English Journal for Translation \& Literary Studies 
misappropriation when he spells the ST على ['alä on] as and hence understands it not as a preposition meaning over, but as a verb meaning "to rise over" (1996, p. 83).

Unlike Tengku Jusoh, and much like Raux, Alan Jones uses the phrase "as far as we could tell." Being aware of the long distance that separated these places from each other, Jones notes that "the place-names throughout the passage are used in a general illustrative way, as they seem to be in the rest of the poem" (1996, p. 83). He supports his argument by quoting "[t]he commentators" who claimed that these three places "cannot all be seen at once from any one place."

\section{Verse Translations}

Of the verse translations, Lyall's (1845-1920) comes first chronologically in the corpus (1885). Lyall was known amongst his contemporaries as a vehemently passionate lover of Arabic poetry; he would recite long poem by heart (Nicholson, 1920, pp. 492-93). His work marks the first attempt in the history of the Mu 'allaqāt translations "to imitate the ST metres and double-hemistich form by being shaped into couplets" (Lahiani, 2008a, p. 49). His translation of this verse line reads as follows:

The right of its mighty rain advanced over kațan's ridge:

The left of its trailing skirt swept Yadhbul and as-Sitar (1885, p. 103).

To begin with, Lyall does not, unlike most prose translators, add any strings to point out the poet's means of perception. In this, he maintains the declarative mode of the original verse line. As he does not modify the mountain names, Lyall implicitly alludes to the fact that Katan is a mountain, and so Yadhbul and Sitār are mountains, too. This allusion is achieved by Lyall's use of the word "ridge" to refer to Qațan.

Lyall focuses on the movement of the cloud. By saying that it "advanced," he infers that it progressed from one place to another. Simultaneously, Lyall creates a metaphor, through which he implicitly compares this cloud to the trail of a woman's skirt. This trail went over the top of Qațan, and then part of it submerged the other two mountains, which means that they were close one to the other. Not only does this metaphor show the distance between these three places, but it also provides a compromise between the ST and the TT universes of discourse. As far as the former is concerned, a hint is made earlier in this same Mu'allaqa, verse line 28, to the poet's beloved trailing her garment behind her to efface her footprints. This hint tracks the source of Lyall's inspiration. This image also evokes a cultural aspect of the TL, as trails on skirts were a part of nineteenth-century English women's clothing. As it achieves harmony between the ST-based tenor and the TT-biased vehicle, this metaphor integrates the ST field. Note, however, that Lyall does not convey the ST poet's reference to the great distance between the mountains, nor does he shed any light on the poet's scope of vision.

Anne Blunt (1837-1917) and Wilfrid Scawen Blunt (1840-1922) produced a collaborative translation of the Mu 'allaqāt (1903). While she rendered the Arabic text into English, he versified her prose translation (1903, p. xxi). The Blunts are known for their admiration of Arabic poetry, 
Arabic culture, and scenery (Lahiani, 2008a, p. 55). They are also known for their use of foreignizing strategies ${ }^{\mathrm{V}}$ in their translation of the $M u$ 'allaqāt with the aim of presenting it as different poetry (Lahiani, 2008a, pp. 55-66; 123-300; Lahiani, 2008b). While handling this verse line, the Blunts shifted its focus from the description of the clouds to the description of the rain, which fits the connotation of the ST word "shaym"vi This shift did not impede reflection of the distance between the mountains:

By its path we judged it: rain over Kāttan is;

far in Sitār it falleth, streameth in Yāthboli (1903, p. 7)

This translation is innovative in the corpus as it makes the first attempt to reveal the progression communicated in the ST through the use of the linker " $f a$." The Blunts modulated the image in such a way as to make the distance between the three mountains functional. They reflect the progression of the strength of the rain through the variation of the verbs used: "falleth" and "streameth." The distance is revealed by the use of the adverb "far." Unlike Lyall, and in line with the tradition established by most of the prose translators before and after them, the Blunts inserted the clause "[b]y its path we judged it" to highlight the poet's field of vision: "By its path" infers that the speaker was talking about something that he could see, while "we judged it" infers his personal estimation of a thing that he did not manage to see. This matches Schmidt's later insertion of the clause "A bien l'observer, j'imaginai."

This translation does not offer much information concerning the setting, and thus, it loses a great deal of the ST communicative clues. Firstly, the Blunts claim that the three places are all far away from one another, which is not accurate, as the ST claims that Qatan is on one side, and both Sitār and Yadhbul are on another. Secondly, the Blunts do not clarify the fact that the proper names refer to the names of mountains in Arabia. At the same time that this conforms to their decision to minimize the insertion of commentaries in and around their text (1903, p. xxi), it contradicts their interest in the desert as the setting of Arabia and the fact that they even went in a trip on camelback across the desert to get the feelings of this setting (Lahiani, 2008a, p. 56).

Like the Blunts before them, Howarth (1900-1971) and Shukrallah (1921-1995) produced a collaborative translation that they published in 1944. They are unique in the corpus as stating in the preface of their work the fact that they relied on "creative impulse" (1944, p. xii) by "giving priority to poetic re-creation at the possible expense of ST servitude" (Lahiani, 2008a, pp. 58-59). Howarth and Shukrallah completely omitted the names of the mountains:

My stretched arm burns in a flash, between shoals

Of crowned cloud, that lean on both flanks of the hills (1944, p. 38)

By adopting such a choice, these translators contradicted the claims that they expressed in the preface of their book: that their translation would follow "the idiom of North English poetry," which "has features congenial to certain Arabic poems, especially some of the most powerful of them" (1944, p. xii). Among these features, they mentioned, "a love of places and place-names" 
(1944, p. xiii). Thus, it is not clear why Howarth and Shukrallah ignored the mountain names. Throughout this work, the only proper names transliterated are those mentioned in verse line 74 .

Besides, Howarth and Shukrallah refer to the mountains as hills, which modulates the ST message, and the image embedded in it. Imru' al-Qays says that the mountains were so high that they reached the clouds. On the contrary, linking the clouds to hills dilutes the impact of the message. Such a loss in the translation may be explained by the translators' condensing the verse lines and mixing them up with the aim of avoiding reader "ennui" (1944, p. xi). This resulting translation is unfocused because the two lines quoted above combine verse lines 72 and 73 of the ST.

Like Howarth and Shukrallah before him, Desmond O'Grady (1935-2014) omits the names of the mountains from his translation (1990, p. 20).

as the storm ranged the wide waste of sky

before downpour.

Then,

Deluge!

This translation does not even infer its original's reference to mountains. Such a choice matches O'Grady's pre-set determination to ignore place names $(1990$, p. 8). This decision impedes his translation from conveying an important ST aspect: its setting. Whereas Howarth and Shukrallah refer to "hills," O'Grady effaces this element. Note that O'Grady used al-Tibrīzī's commentary that was edited by Lyall in addition to his familiarity with the translations done by Arberry, Bateson, Lyall, and the Blunts (1990, p. 9). His intention was not to produce "scholarly translations" (p. 8); it was, rather to produce literature that would appeal to its new receiver.

O'Grady's translation adheres to the shaped verse genre. ${ }^{\text {vii }}$ The metrical expansion of the first line above imitates the expansion of the clouds as evoked in the ST. This expansion is reinforced by the alliteration achieved with the repetition of the glide non-obstruent sound /w/ and by the assonance achieved with the repetition of the diphthong/ai/. A metrical foot diminution is exercised as soon as "downpour" is predicted ("before"). Suspense is created by the full stop that closes the second line and hence leaves the reader's curiosity suspended. This is brought into a climax by the one-worded line "Then." The climax is fulfilled here semantically as well as visually since it is manifested by another metrical foot diminution. This diminution is stabilized in the fourth line with the resolution achieved by the "deluge" that came as a consequence of the cloud/metrical expansion. These modulations do not compensate for the loss resulting from O'Grady's omission of the place names and their connotations concerning space.

Arberry (1905-1969) was aware of most of the translations that were produced before his (Lahiani, 2008a, p. 60). The following couplet is his rendering of Imru' al-Qays's verse line:

over Katan, so we guessed, hovered the right of its deluge, its left dropping upon Es-Sitār and further Yadhbul (1957, p. 66)

Arab World English Journal for Translation \& Literary Studies 
Arberry shifts the poet's perception toward the intellect by inserting the phrase, "so we guessed." This deviates from the meaning of the ST "shaym." Likewise lost in this translation are the referents of the proper nouns. Much like the Blunts and Schmidt, Arberry shifts attention in his translation between the clouds and the rain. By using a compensation in kind, ${ }^{\text {viii }}$ Arberry claims that the deluge "hovered" in one place and then dropped in another, which assumes the great distance between these places, hence the degree of the expansion of the cloud. In this respect, Arberry's use of "further" to translate the ST linker " $f a$ " is functional. This path was followed later by Wormhoudt (1917-) and then by Berque (1910-1995).

On Qatan the glance of a right hand shower

Its left on Sitar and then Yadhbul (Wormhoudt, 1974, p. 4)

Sur Qat'an nous guettions la dextre de la pluie

Sa gauche sur al-Satār puis Yadhbul (Berques, 1979, p. 74)

[On Qat'an we watched the rain right side. Its left was on Satār and Yadhbul].

The chief difference between Arberry's translation and these TTs is that Wormhoudt and Berque maintain the visual perception that is inferred in the original texts by using, respectively, "the glance of" and "nous guettions."

Both Nouryeh (1940-) and Stetkevych (1950-) maintain the names and explain their referents:

watching the far-off

rains slop Qatana crest on the right

and pelt Sitari and Yathbuli hills on

the left (Nouryeh, 1993, pp. 60-61)

Over Mount Qatan, as I read the signs, the right flank of its downpour falls, Over Mount al-Sitār, then Mount Yadhbul, falls the left (Stetkevych, 1993, p. 256)

While Stetkevych integrates the word "Mount" in her lines to modify the proper names, Nouryeh adopts in conveying the first name the method coined by Lyall long before him: he uses the word "crest," which is commonly a term used to describe mountains. Also, he explains in an endnote that "Qatana" is the "name of a mountain" (1993, p. 64). It is thus unfortunate that he refers to Sitār and Yadhbul as "hills." The preservation of the poet's visual perception is another aspect that the two translations have in common. Whereas Nouryeh uses the verb "watching", Stetkevych adds the clause "as I read the signs." The difference between the two TTs is that, whereas Nouryeh indicates the short distance between Sitār and Yadhbul as opposed to their remoteness from Qatan, Stetkevych uses the adverb "then", much like Arberry when he used "further", to reflect the distance between the mountains mentioned. It follows that Stetkevych's translation is much more accurate than Nouryeh's due to its reference to mountains as well as to its preservation of the distance relativity, as in the ST.

Arab World English Journal for Translation \& Literary Studies 
Like Stetkevych, Larcher (1948-) uses "puis" (then) to reflect the distance between the second and third mountains:

Sur Qatan, épiée, la droite de l'orage

Et sa gauche, sur el-Sitār, puis sur Yadhboul" (2000, p. 55)

[On Qatan, the right of the storm was watching secretly

Its left, on el-Sitār, then on Yadhboul]

Larcher does not clarify that the proper nouns refer to mountains, much like many translators before him. He uses the verb "épiée", which means to watch secretly. This fits in with conveying not only the visual perception of the ST poet, but also the general context: as the cloud was as thick as the poet described it, he had to seek shelter to watch the rain develop. Lost in this translation, though, is the core of the ST verse, which is the distance between the mountains and, hence, the spaciousness of the landscape.

\section{Conclusion}

As advanced in the introduction, this verse line by Imru' al-Qays bears at least two communicative clues. The first is its nominal reference to mountains in the desert of Arabia. The second is that these mountains, though distant, were simultaneously visible to the watchful poet as explained by the ST commentaries quoted above. The critical evaluation above shows that, because of the geographical remoteness between the original poet and his receivers, on the one hand and the receivers of the translations on the other hand, it is essential that a translator adopt a TT-oriented translation strategy for his/her rendering is effective, and adequate. In the corpus examined in this article, some translators added words to modify the proper nouns, namely W. Jones, Caussin de Perceval, Raux, and Schmidt. Although they did not add modifying adjectives, Lyall, and Nouryeh used vocabulary words associated with mountains. Johnson, the Blunts, Arberry, Bateson, Wormhoudt, Berque, Ghani Tengku Jusoh, Alan Jones, and Larcher adopted a source-text-oriented strategy for dealing with this aspect, hence refraining from adding references or inferences that the names refer to mountains and not relating this communicative clue.

The field of vision is another challenge for the translators, as it also required the addition of explanatory strings. Wormhoudt, Berque, Nouryeh, and Stetkevych adopted this technique, and they made it clear to their readers that the poet managed to see the scene despite the great distance. Johnson, Arberry, and Bateson did not perceive the importance of the scene as being in the poet's field of vision, and they modulated it toward the speaker's scope of imagination. The Blunts' resolution may stand mid-way, as the clause "[b]y its path we judged it" refers to both the visual and the intellectual perceptions.

The target-text-oriented technique of the addition of words is essential to this work. However, its efficiency depends on the translator's awareness of the source text's communicative clues. Howarth and Shukrallah aimed to produce a text that would vibrate poetry and spare its reader any "ennui." The outcome is a line that shows a minimal relationship with its original. Likewise, 
O'Grady omitted the names and all references to the mountains. He created a shaped verse. These modulations result in pleasant modern poetry, which lines up with the translator's aim, but the communicative clues of the ST are not in evidence.

This comparative work has shown that artistic sensibility merges into a whole with its locale. Subjected to translation, this sensibility may be lost, and the message hence transformed if the translator does not show awareness of the thematic importance of the ST landscape in the process of their work. As Dainotto (2000) suggests, a poet "speaks from one specific place of cultural production, and about a localized 'geography of the imagination' within whose borders a given literary utterance may remain significant, relevant, and even intelligible” (p. 3). Naturalistic descriptions are essential in a text insofar as they link it to its environment and build-up to its intended message. Their significance "arises from the truth's need for strong foundations, not with any restriction of scope" (Stafford, 2010, p. 17). Such descriptions lose their communicative functions when a translator is not aware that both the ST poet and the ST receiver share an essential familiarity with the landscape that the TT receiver does not have. The translations that manage to convey the communicative functions of landscape are those that compensate through the addition of modifiers and the highlighting of the speaker's field of vision.

\section{About the Author:}

Raja Lahiani holds a PhD degree from SOAS, The University of London. She is the author of Eastern Luminaries Disclosed to Western Eyes (2008). She also has articles in the fields of comparative literature and translation studies published in scholarly peer-reviewed journals. She has been teaching in different universities across Tunisia, KSA and the UAE.

https://orcid.org/0000-0003-3774-8568

\section{References}

Al-Anbārī, A. M. Q. B. (2008). Sharh Al Qașā’id al-Sab 'al-Ṭiwāl al-Jāhiliyyāt. Beirut: Dār alMa'ārif.

Al-Naḥḥ̄ā, A. J. A. M. (1973). Al Qaṣā’id al-Tis‘ al-Mashhūrāt. Baghdad: Dār al-Hurriyah liTibā'ah.

Al-Shanqīṭ̄i, A. B. A. (2018). Al Mu'allaqāt al 'Ashr wa Akhbār Shu 'arāihā. Windsor: Hindāwī CIC.

Al-Tibrīzī, A. Z. Y. (1894). Kitāb Sharh al-Qașā'id l- 'Ashr, edited by Charles James Lyall. Calcutta: Dār l-Imāra.

Al-Zawzan̄i, A. A. H. (2013). Sharh al-Mu 'allaqāt al-Sab’. Lebanon: Al Maktabah al Aṣrihhah. Arberry, A. J. (1957). The Seven Odes. The First Chapter in Arabic Literature. London: George Allen and Unwin Ltd.

Baker, M. (2014). Translation as Re-narration. In J. House (Ed.), Translation: A Multidisciplinary Approach (pp. 158-177). New York: Palgrave Macmillan.

Bateson, M. C. (1970). Structural Continuity in Poetry. A linguistic Study of Five Pre-Islamic Arabic Odes. Paris: Mouton and Co. 
Benneghrouzi, F. Z. (2019). Beyond Literalism: Arberry's Translating (in) Visibility of Imru al Qays' Mu'allaqa through the Lens of Critical Discourse Analysis. Translation and Literary Studies, 3(1), 145 -156.

Berque, J. (1979). Les Dix Grandes Odes Arabes de l'Anté-Islam. Paris: Sindbad.

Blunt, A. \& Scawen, W. (1903). The Seven Golden Odes of Pagan Arabia, Known also as the Moallakat. Translated from the Original Arabic by Lady Anne Blunt. Done into English Verse by Wilfrid Scawen Blunt. London: Chiswick Press.

Calfoglou, C. (2010). An Optimality Approach to the Translation of Poetry. In A. Fawcett, K. L. G. Garcia and R. H. Parker (Eds.), Translation: Theory and Practice in Dialogue (85-106). London: Continuum.

Caussin de Perceval, A. P. (1847). Essai sur l'Histoire des Arabes Avant l'Islamisme, Pendant l'Epoque de Mahomet, et Jusqu'à la Réduction de Toutes les Tribus sous la Loi Musulmane. Paris: Librairie de Firmin Didot Frères.

Colina, S. (2015). Fundamentals of Translation. Cambridge: University Printing House.

Dainotto, R. M. (2000). Place in Literature: Regions, Cultures, Communities. Ithaca and London: Cornell University Press.

Enkvist, N. E. (1978). Contrastive Text Linguistics and Translation. In L. Grahs, G. Krlen, and B. Malmberg (Eds.), Theory and Practice of Translation. Berne: Peter Lang.

House, J. (2014). "Translation Quality Assessment: Past and Present In J. House (Ed.), Translation: A Multidisciplinary Approach (pp. 241-264). New York: Palgrave Macmillan.

Howarth, H. \& Shukrallah, I. (1944). Images from the Arab World. Fragments of Arab Literature Translated and Paraphrased with Variations and Comments. London: The Pilot Press Ltd.

Hussein, A. A. (2009). The Lightening-Scene in Ancient Arabic Poetry: Functions, Narration and Idiosyncrasy in Pre-Islamic and Early Islamic Poetry. Wiesbaden: Harrassowitz.

Johnson, C.F. E. R. A. (1894). Al Sab' Mu 'allaqūt. The Seven Poems Suspended in the Temple at Mecca. Translated from the Arabic by Capt. F. E. Johnson, R. A. With an Introduction by Shaikh Faizullabhai, B. A. London: Luzac \& Co.

Jones, A. (1996). Early Arabic Poetry: Select Odes. Edition, Translation and Commentary. Reading: Ithaca Press.

Jones, W. (1782). The Moallakät, or Seven Arabian Poems, which were Suspended on the Temple at Mecca; with a Translation, a Preliminary Discourse and Notes. London: Elmsly.

Jones, W. (1970). The Letters of Sir William Jones. Garland Cannon (ed.). Oxford: Clarendon Press.

Kuntz, M. (1993). Narrative Setting and Dramatic Poetry. Leiden, New York and Koln: E. J. Brill.

Lahiani, R. (2008a). Eastern Luminaries Disclosed to Western Eyes. A Critical Evaluation of the Translations of the Mu'allaqât into French and English (1782-2000). New York, Bern: Peter Lang.

Lahiani, R. (2008b). Translation as an Intercultural Exercise. The Pioneering Translations of the Mu'allaqât. In S. Linn, M. Mous and M. Vogel (Eds.), Translation and Interculturality: Africa and the West (pp. 73-85). Bern: Peter Lang.

Lahiani, R. (2009). The Relevance of the Glance of the Roe of Wajra: A Comparative Study of the Translation of a Culture-based Metaphor. Translation and Interpreting Studies, 4(1), 31-46. 
AWEJ for Translation \& Literary Studies Volume, 4 Number 3 August 2020

Landscape in Literary Translation: A Comparative Study

Lahiani

Lane, W. E. (1863). An Arabic-English Lexicon, Derived from the Best and the Most Copious Eastern Sources. Edinburgh: Williams \& Norgate.

Larcher, P. (2000). Les Mu'allaqāt: Les Sept Poèmes Préislamiques. Saint-Clément-de-Rivière: Fata Morgana.

Lyall, C. J. (1885). Translations of Ancient Arabian Poetry, Chiefly Pre-Islamic, with an Introduction and Notes. London and Hertford: Williams \& Norgate.

Nouryeh, C. (1993). Translation and Critical Study of Ten Pre-Islamic Odes. Traces in the Sand. Lewiston, Queenston and Lampeter: The Edwin Mellen Press.

O'Grady, D. (1990). The Seven Arab Odes. An English Verse Rendering with Brief Lives of the Seven Poets. Dublin: Agenda Editions.

Pym, A. \& Horst T. (2004). Translatability. In M. Baker (Ed.), Routledge Encyclopedia of Translation Studies (pp. 273-277). London: Routledge.

Raux, A. (1907). La Mo 'allaka d'Imrou'l Kaïs Suivie de la Douzième Séance de Harırl, Dite de Damas, et de la Kasêda ezZaïnabiyya, Poëme Attribué à Ali / Textes Publiés avec les Voyelles, un Commentaire Arabe et une Traduction Littérale en Français. Paris: E. Leroux.

Schmidt, J. (1978). Les Mou 'allaqat, ou un Peu de l'Ame des Arabes avant l'Islam. Paris: Seghers. Shamma, T. (2009). Translation and the manipulation of difference: Arabic literature in nineteenth-century England. Oxon: Routledge.

Stafford, F. (2010). Local Attachments. The Province of Poetry. Oxford: Oxford University Press.

Stetkevych, S. P. (1993). The Mute Immortals Speak. Pre-Islamic Poetry and the Poetics of Ritual. Ithaca and London: Cornell University Press.

Tengku Jusoh, T. G. (1990). A Critical Examination of Five Poems by Imriu al-Qays. Kuala Lumpur: Penerbitan Pustaka Antara.

Underhill, J. (2016). Voice and Versification in Translating Poems. University of Ottawa Press Venuti, L. (2013). Translation Changes Everything. Theory and Practice. New York: Routledge. Wormhoudt, A. (1974). The Diwan of Imru al Qais ibn kinda ibn Qahtan. Diwan al Khirniq bint Badr ibn Hiffan. Akhbar of Sulaik. Iowa: William Penn College.

\section{Notes:}

\footnotetext{
i "Mu'allaqa" is the singular of "Mu'allaqāt" in Arabic.

ii A few works have explored broader issues related to the translation of this work, particularly the challenges inherent in successfully rendering Classical Arabic metaphor and other linguistic elements into Western languages: The application of semantics to the translation of pre-Islamic poetry: with special reference to the'Mu'allaqa'of Imru al-Qays (Husayn, 1984); Eastern Luminaries Disclosed to Western Eyes (Lahiani 2008a, pp. 285-300); “The relevance of the glance of the roe of Wajra: A comparative study of the translation of a culture-based metaphor" (Lahiani, 2009); Beyond Literalism: Arberry's Translating (in) Visibility of Imru al Qays' Mu'allaqa through the Lens of Critical Discourse Analysis (Abu-Zeid, 2019).

iii Lane's (1863), Al-Nahhās' (1973), and Al-Anbārì's (2008) definition of the word "shaym" with reference to clouds and the poet's ability to see them, refutes Hussein's (2009) understanding of this term as meaning “out-of sight places" and its verb derivative as meaning "to estimate" (p. 49).

iv Biographical information about this translator is rare.

' Tarek Shamma takes a different view as he rather refers to the Blunts' domesticating strategies in the third chapter of his book entitled "Domestication as Resistance: Wilfrid Scawen Blunt's Translations from Arabic" (2009, pp. 86120). According to Shamma, "the familiarizing techniques [the Blunts] used were intended to combat stereotypes about Arab culture" (2009, pp. 5-6). In contrast, the comparative work done in Lahiani $2008 \mathrm{~b}$ proves that by
}

Arab World English Journal for Translation \& Literary Studies 32

ISSN: 2550-1542 |www.awej-tls.org 
unnecessarily borrowing lexical items from Arabic (not all of them used in the ST), as in their imitations of Arabic structures and rhymes many of which turn into doggerel, the Blunts unintentionally foreignized this text. Contrary to Shamma's assertion, Culture is just one of the features that the Blunts targeted in the Mu 'allaqāt. They gave versification no less importance. They reflect in the introduction of their work their objective that the $M u$ 'allaqāt may enrich the English canon. This justifies their characterizing them as a "wild flower" and as attractive to lovers of "strange and beautiful verse" (1903, pp. ix; xix).

vi The Blunts (1903) used al-Shinqīị̂̄’s commentary (p. xx). Al-Shinqīị̄i does not expand on the meaning of this verse line. He only comments on its grammatical structure (2018, p. 79).

${ }^{\text {vii }} \mathrm{O}$ ' Grady makes some serious attempts with shaped verse in his translations of the Mu 'allaqāt. The functionality of shape in O'Grady's translations is detailed and evaluated in Lahiani, 2008b, pp. 221-222.

viii Arberry adopts the same ST-oriented strategy when translating the first verse of this same Mu 'allaqa. In the context of her evaluation of this translation, Benneghrouzi notes that this choice as adopted by Arberry rather weakens the effect that could have possibly been created: "The effect that the place referents produce in the original with all the wholeness they impart is lost in the literal translation by Arberry" as it quotes names with no clear referents (2019, p. 151). 